\title{
Factors affecting the retention of Generation X public servants: An exploratory study
}

\author{
Authors: \\ Vhutshilo Masibigiri ${ }^{1}$ \\ Hester Nienaber ${ }^{2}$ \\ Affiliations: \\ ${ }^{1}$ HR Manager, Inland, \\ Packnstack, Hatfield, \\ South Africa \\ ${ }^{2}$ Department of Business \\ Management, Unisa, \\ South Africa \\ Correspondence to: \\ Hester Nienaber \\ Email: \\ nienah@unisa.ac.za \\ Postal address: \\ PO Box 392, Unisa 0003, \\ South Africa \\ Dates: \\ Received: 05 Aug. 2010 \\ Accepted: 25 Jan. 2011 \\ Published: 25 Mar. 2011 \\ How to cite this article: \\ Masibigiri, V., \& Nienaber, \\ H. (2011). Factors affecting \\ the retention of Generation \\ $X$ public servants: $A n$ \\ exploratory study. SA \\ Journal of Human Resource \\ Management/SA Tydskrif vir \\ Menslikehulpbronbestuur, \\ 9(1), Art. \#318, 11 pages. \\ doi:10.4102/sajhrm.v9i1.318
}

C 2011. The Authors. Licensee: OpenJournals Publishing. This work is licensed under the Creative Commons Attribution License.
Orientation: Retaining employees, especially Generation Xers, is imperative to ensure the high performance of organisations.

Purpose: The purpose of this study was to explore the factors that affect the retention of Generation X public servants.

Motivation for the study: Given their unique characteristics, it is a challenge to retain Generation X employees. This problem may be worse in the public sector than in the private sector, as there are fewer financial rewards in the public service than in the private sector.

Research design, approach and method: The interpretivist paradigm is appropriate for this study. It used a qualitative, empirical approach. The researchers obtained the data through purposive sampling and interviews.

Main findings: The study showed that the factors affecting the retention of Generation $X$ public servants include work content, utilisation of skills, career advancement, work-life balance, compensation, security needs, leadership and drive.

Practical/managerial implications: Employers, like the civil service, can be proactive in retaining Generation X employees because of the factors that affect their retention. Managers can prevent further pressure on service delivery that the skills shortage has caused if they use the skills the employees already have.

Contribution/value-add: The article fills a gap, as there has been little research on staff retention. This is particularly true of Generation X employees in South Africa. This article adds information that will improve retention strategies for Generation X employees, particularly in the public service.

\section{Introduction}

The world of work has changed during the last two decades because of globalisation, technological advances, new ways of doing business and even new forms of organisations to meet changing market demands and to keep ahead of competitors (Holbeche, 2009; Vittori, 2007).

The changing world of work also saw the advent of the 'knowledge worker'. This changed employees' (called 'talent') needs. Consequently, talent and their employment are at the forefront of business agendas to ensure high performance (Harvey, 2009; Linne, 2009).

Because talent is not submissive, employers should respond to their changing needs in order to ensure continuous, appropriate and successful responses to changing market needs (Holbeche, 2009).

Therefore, it is imperative that organisations attract, develop and retain the right talent at all levels to ensure their ongoing competitive advantage vis-à-vis competitors (Bersin, 2008; Boxall, 1998; Grant, 1996, 2010; Heinen \& O’Neill, 2004; Peteraf, 1993; Truss \& Gratton, 1994).

Retaining the right talent in South African organisations, as is the case internationally, is challenging because of recent phenomena like the struggle for talent, skills shortages, employee mobility and the imminent retirement of baby boomers. This situation will become worse if organisations do not handle recessionary layoffs properly. These phenomena adversely affect the ability of organisations to create and maintain their competitive advantage and their consequent performance. 
Generation X employees are losing their trust in, and loyalty to, their organisations and fear boredom. Organisations must retain them if they are to create and sustain their competitive advantage. Generation X employees are human capital repositories of knowledge, skills and expertise, and ensure good performance.

Retaining Generation X employees, in particular, is important for both the private and public sectors. The retention problem may even be worse for the public sector as there are fewer financial rewards in the public service than in the private sector $^{1}$ (Niewenhuizen, 2009).

The skills shortage ${ }^{2}$ (Sherry, 2008) and high vacancy rates ${ }^{3}$ put pressure on service delivery, especially in the public

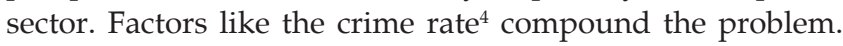
It leads to emigration and reduces capacity in the public sector. Black Economic Empowerment (BEE) requirements are not helping because of the lack of appropriately qualified and experienced candidates, especially in the case of senior management posts (Temkin, 2008, 2009). Senior managers play an important part in retaining staff because they are responsible for managing talent, of which retention is an integral part, in organisations.

The response of traditional employers to staff retention is reactive in nature. They try to decrease the desire of staff to leave (De Vos \& Meganck, 2009; Williams, 2008). This approach, however, is seldom successful - once people have expressed the desire to leave, efforts to retain them may already be too late (Mosley \& Hurley, 1999). Furthermore, the changing competitive landscape necessitates a different approach to staff retention (Pfau \& Kay, 2002) if the organisation wants to succeed and prosper in the long term.

Retention has recently received increased attention in the literature, either separately or as part of talent management strategies. The significance of retention stems from the integrated nature of managing talent. This is the implementation of integrated strategies and systems to ensure high performance by developing improved processes of attracting, developing, retaining and using people with the required skills and aptitudes to meet current and future business needs (Lockwood, 2006).

Despite the plethora of literature on retention, organisations' responses to the needs of talent in contemporary times appear to be unsuccessful and jeopardise high performance. Retention is important for organisations as it ensures that they have the right skills at all levels and occupations to enable them to achieve their goals, especially that of high

1.See Saratoga Institute, 2005, in Munsamy \& Bosch-Venter, 2009.

2.See Business must resolve dire skills shortage. (2008). Business Day, 18 November. Available at http://bis.hosted.inet.co.za/news; Dearth of supply chain skills. (2008). Business Times, 25 May. Available at http://bis.hosted.inet.co.za/news; Shortage of skills across the board. (2008). Business Day, 23 July. Available at http://bis. of skills across the board. (2008). Business Day, 23 July. Available at http://bis. August. Available at http://bis.hosted.inet.co.za/news.

3.Parastatals need to fill 6000 jobs (2010). Cape Times, 18 May 2010.

4.Operation getthehellout. (2008). Business Day, 19 April. Available at http://bis. hosted.inet.co.za/news. performance. News coverage shows that goal achievement and high performance are current challenges, especially for the South African public sector (Jeffrey, 2010).

The purpose of this article is to report on an exploratory study amongst Generation X public servants in South Africa in 2008 about the factors that affect their retention and the strategies to retain them.

The research question was 'What factors affect the retention of Generation X public servants in South Africa?' This would serve as basis for developing retention strategies for Generation X public servants.

The article fills a gap as there has been little research so far in the area of staff retention in general (Kontoghiorghes \& Frangou, 2009) and in South Africa in particular (KerrPhillips \& Thomas, 2009), especially of Generation X employees (Munsamy \& Bosch-Venter, 2009).This article offers information that will assist the development of retention strategies for Generation X employees, particularly in the public service.

The next section presents a review of the literature on retention with specific reference to Generation X. An exposition of the methodology used in the study follows. Thereafter the article presents and discusses its results. The article closes with conclusions and recommendations.

\section{Synthesis and critical evaluation of the literature}

This section highlights retention with specific reference to Generation X employees. The section touches on the costs associated with leaving and retention versus turnover briefly. It presents the factors that affect the retention of Generation $X$ employees and specific strategies to retain them in more detail. The latter is the specific focus of the research.

Retaining talent refers to employers' efforts to create an environment that engages employees for the long term and ensures that they keep desirable workers in order to meet business objectives (Frank, Finnegan \& Taylor, 2004). However, if employees are not satisfied with these efforts they can leave. Therefore, retention results from mutual satisfaction between employees and employers and occurs voluntarily (Kontoghiorghes \& Frangrou, 2009).

Retaining talent is important because staff members that leave organisations incur direct and indirect costs.

The direct costs of recruiting new employees include the costs of recruitment agencies, interviewing and assessing prospective candidates and finding replacements whilst the recruitment process is underway. They include training and development costs, as well as the cost of severance packages or dismissal if the organisation employed the wrong candidates in the first place. Organisations can calculate direct costs easily as they link to specific activities (Hillmer, Hillmer \& McRoberts, 2004). 
Indirect costs pertain to knowledge, especially tacit knowledge, which employees take with them when they leave. Losing tacit knowledge is detrimental to achieving long-term competitive advantage, organisational objectives and high performance. Organisations cannot easily calculate the indirect costs, like the knowledge specific employees have, and their contributions to creating competitive advantage, achieving goals and high performance. They may far outstrip the direct costs of staff turnover.

High performance and competitive advantage go together. Competitive advantage explains and predicts why some organisations are able to achieve and sustain performance that yields higher returns (Carpenter \& Sanders, 2009; David, 2009; Grant, 2010; Hough, Thompson, Strickland \& Gamble, 2008; Ireland, Hoskisson \& Hitt, 2009; Pearce \& Robinson, 2009).

In its simplest form, competitive advantage means that organisations make it easier for customers to do business with them than with their competitors because of the value they offer to customers (Kotler \& Armstrong, 2000). The crux of competitive advantage is the ability of managers to use their current unique bundles of resources and capabilities in ways that maximise value whilst they develop the resources and capabilities they need for the future (Grant, 2010; Helfat \& Peteraf, 2003; Peteraf, 1993).

Of all the resources at firms' disposal, knowledge is the most important (Brown, 2009). This is because talent, especially Generation X employees, is seen as the knowledge repositories of organisations and is one of the building blocks of organisations' competitive advantage (Bersin, 2008; Boxall, 1998; Cunningham, 2007; Grant, 2010; Heinen \& O'Neill, 2004; Helfat \& Peteraf, 2003; Peteraf, 1993; Truss \& Gratton, 1994). Therefore, retaining them is important for creating and sustaining competitive advantage as well as ensuring high performance.

Retention has recently received increased attention in the literature as an entity on its own (Ahlrichs, 2007; Cheney \& Nienaber, 2009;DeMarco,n.d.;DeVos\& Meganck, 2009; Frank et al., 2004; Hillmer et al., 2004; Jamrog, 2004; Kerr-Phillips \& Thomas, 2009; Kontoghiorghes \& Frangou, 2009; Linne, 2009; Munsamy \& Bosch-Venter, 2009; Pillay, 2009; Salopeck, 2008; Schachter, 2009; Smith, 2009). Retention is also seen as part of talent management, of which it forms an integral part (Bersin, 2008; Boxall, 1998; Cook \& Macauley, 2009; Fegley, 2006; Harvey, 2009; Heinen \& O’Neill, 2004; Kesbey, 2008; Lee \& Maurer, 1997; Lewis \& Heckman, 2006; Lockwood, 2006; Mosley \& Hurley, 1999; Naveen, 2000). However, according to Kontoghiorghes and Frangou (2009), the literature on retention is not as abundant as that on turnover, which also deals with employees leaving organisations. The different concepts require different approaches to retain employees or to deter them from leaving.

Previous research has demonstrated that retention, whether in the private or public sector, is a multi-faceted construct that a number of drivers affect. They include employee commitment, especially affective and normative commitment (Abbott, White \& Charles, 2005; Joseph, Ng, Koh \& Ang, 2007; Meyer, Allen \& Smith, 1993; Samuel \& Chipunza, 2009), engagement (Dewhurst, 2009; Frank et al., 2004); communication (DeMarco, n.d.; Perrine, 2009); leadership and interaction (Dyer, 2009; Perrine, 2009; Samuel \& Chipunza, 2009); and specific human resource (HR) practices (Bova \& Kroth, 2001; Rose \& Gordon, 2010; Samuel \& Chipunza, 2009).

Commitment and engagement correlate negatively with turnover or the intention to leave the organisation. Affective commitment reflects an emotional attachment to, and identification with, organisations. Normative commitment, on the other hand, mirrors a sense of belonging (Meyer \& Smith, 2000). Affective commitment is sensitive to experience whilst normative commitment can develop in response to social pressures (Powell \& Meyer, 2004). Engaged employees are those who know what their organisations do, can articulate their competitive advantage accurately and passionately, care about their customers and communicate with colleagues even in informal settings (Dyer, 2009). Generation Xers value communication because it facilitates participation in true exchanges of ideas and ensures that others hear and understand messages (Perrine, 2009; Schachter, 2009; Vaughn, 2008). Communication per se is important for creating commitment and engagement.

Generation Xers prefer leadership behaviours that are associated with generational themes, especially flexibility, recognition and challenging working conditions (Cordeniz, 2002; Perrine, 2009; Pfau \& Kay, 2002; Rodriquez, Green \& Ree, 2003; Salopek, 2008). They also contribute to the commitment and engagement of Generation Xers. HR practices that promote the retention of Generation X employees include flexible working arrangements, recognition, training (including mentoring), development, and performance management (including feedback).

In the case of public servants like nurses (Perrine, 2009) and engineering and technical professionals (Rose \& Gordon, 2010) competitive remuneration is another factor that affects the retention of Generation Xers. These HR practices overlap with leadership as well as commitment and engagement. They also foster commitment and engagement.

The different drivers that affect retention interact with one another, illustrating that retention is indeed a multi-faceted concept. Furthermore, this information shows that retention is a delicate matter that needs careful attention to ensure that employees remain and preserve the knowledge, skills and experience necessary for continuity. In the case of Generation $X$ employees, these drivers feed their unique characteristics particularly.

It is more challenging to retain Generation $X$ employees. They are more likely to leave when dissatisfied than any other generation because of their unique characteristics and 
different sets of goals, aspirations and values (Ahlrichs, 2007; DeMarco, n.d.; Johnson, 2004; Western \& Yamamura, 2006).

Generation Xers, born between 1965 and 1981 (Bova \& Kroth, 2001), often grew up alone because their parents worked and many of their parents had divorced (Cordeniz, 2002). Consequently, Generation Xers are concerned about life balance. They are also protective of the family (DeMarco, n.d.).

Furthermore, they tend to be sceptical and pragmatic and value leadership by competence (Cordeniz, 2002). They have no respect for service, title or rank because their parents had it all but lost their jobs anyway (DeMarco, n.d.). Generation Xers are independent, need to belong and want meaningful work (Perrine, 2009; Vaughn, 2008).

However, they consider life experiences more important than work (Johnson, 2004). They tend to be loyal to their skills rather than to their employers. Therefore, they have no objection to crossing borders in order to augment and hone their skills (Ruch, 2000). This makes it difficult to retain this generation (Johnson, 2004). According to Cordeniz (2002), Generation Xers change jobs on average once every $3 \frac{1}{2}$ years. These unique characteristics of Generation Xers tie in with factors that affect retention, especially commitment, engagement, leadership and HR practices.

To protect the contributions of Generation Xers, especially public servants, to achieving goals and high performance, the literature suggests specific strategies for retaining them.

Generation Xers need to be provided with flexibility that meets their needs; Generation X employees require flexibility in working time, work and rewards (Cordeniz, 2002; Johnson, 2002; Rose \& Gordon, 2010).

Flexibility in working time includes flexibility in lifestyle. Generation X employees sometimes prefer time off for doing overtime work, saving commuting time by working from home and flexible work schedules (Withers, 2001). Generation X employees might also prefer compensation in time rather than money (Johnson, 2002). Flexible work might include tackling a challenging task they can accomplish in a workday. Although Generation X employees prefer challenging work environments, the environments should be fun to work in, although they do not have to be secure (Bova \& Kroth, 2001; Perrine, 2009; Rodriquez et al., 2003).

Flexible work arrangements include flexible rewards. This is a manifestation of recognition, something Generation $X$ employees value (Ahlrichs, 2007; Perrine, 2009). Equitable pay is part of recognition, which means a competitive salary based on work performance irrespective of gender and seniority (Ahlrichs, 2007). Flexibility reflects the aptitudes of Generation X employees, which should align with the strategy of the organisation to ensure goal achievement and high performance.
Appropriate leadership needs to be provided for Generation $X$ employees. Leadership plays an important role in meeting the needs of employees and, in particular, the needs of Generation X employees. This means that Generation Xers need leaders with different styles and attitudes (Bova \& Kroth, 2001; Cordeniz, 2002; Rodriquez et al., 2003). Different styles and attitudes are particularly conducive to building relationships (Alrichs, 2007).

Leadership is one of the key factors for retaining employees. The Saratoga Institute (in Ashby \& Pell, 2001) supports this. It states that the relationship workers have with their bosses determines $50 \%$ of work-life satisfaction. The style of manager-leaders has a profound effect on retention, especially that of Generation Xers. According to Taylor (2002) and Cordeniz (2002), employees want leaders who know and understand them, treat them fairly and are people they can trust. Manager-leaders should be able to build trust, esteem and high performance. Manager-leaders must communicate with Generation Xers about their job-related likes and dislikes (Cordeniz, 2002). This means that managerleaders provide employment experiences (Salopek, 2008) where organisational values are compatible with individual ones (Taylor, 2002). As soon as Generation X employees think that their values are incompatible with those of their organisations, they are prepared to leave.

Generation X employees think that opportunity, regardless of age or tenure, and being surrounded by talented peers (Ahlrichs, 2007), is part of the employment experience. Leadership has a decisive effect on commitment and engagement, and influences the decisions of Generation Xers to stay or leave.

Generation X employees should be provided with opportunities for growth. Generation X employees are loyal to their skills rather than to their employers. Therefore, they put a premium on learning and growth (Cordeniz, 2002; Rose \& Gordon, 2009; Ruch, 2000). Again, leader-managers play important parts in ensuring that the skills of Generation Xers are developed as well as used. Cordeniz (2002), Dibble (1999) and Flaherty (2005) emphasise that learning (training) is necessary to retain Generation $X$ employees and to keep them energised and committed. Alrichs (2007) and Vaughn (2008) point out that employees can learn in ways other than through training.

Organisations can create diverse environments because Generation Xers feel that they can learn from the experiences of others. Career development, like performance management, succession planning, promotions, lateral moves and temporary assignments, are other ways Generation Xers can hone their skills (DeMarco, n.d.; Rose \& Gordon, 2010; Salopek, 2008; Schachter, 2009; Taylor, 2002; Vaughn, 2008). If these activities are ongoing rather than haphazard or sporadic, they can ensure continuity (Taylor, 2002) of employment.

Open communication plays an important role in developing careers (Pfau \& Kay, 2002). It is critical for Generation X employees to feel that they are contributing and are trusted with some control over their work (Ruch, 2000). 
Generation X employees also need developmental feedback in order to produce good results. Organisations can use this feedback as retention tools if it is relevant to the job, specific and timely (Dibble, 1999).

In summary, these specific strategies to retain Generation $X$ show that intrinsic work factors (DeMarco, n.d.; Johnson, 2002; Schachter, 2009; Smith, 2009; Taylor, 2002; Vaughn, 2008; Withers, 2001) are important to Generation Xers.

These strategies influence the commitment and engagement that are important to retention. In addition, Holbeche (2009), Salopek (2008) and Vaughn (2008) propose that these strategies show that retention continues the process of recruiting staff with aptitudes and skills that align fully with organisational strategies.

In addition, the retention strategies specific to Generation $X$ employees clearly show that organisations really need a strategic approach that differs from the traditional and reactive one HR departments use. Research has found that HR departments tend to focus on factors that researchers believe cause turnover rather than those that promote retention.

\section{Research design Research approach}

A researcher's philosophical assumptions do influence an inquiry, although research largely hides them (Creswell, 2009), by explaining why things are the way they are for the researcher (Henning, Van Rensburg \& Smit, 2004).

An interpretivist research philosophy, with its emphasis on experience and interpretation, is appropriate to this study.

Interpretive research is concerned with meaning and tries to understand how people interpret social reality. In this instance, the research tries to understand the factors that influence the retention of Generation X public servants.

The interpretive philosophy is congruent with the purpose of this research because it explores Generation X public sector employees' perceptions of factors that influence their retention. Descriptions of the participants' perspectives of social reality provide data that form the basis of themes and categories about these factors that we can use to develop retention strategies for Generation X public servants.

The interpretivist philosophy is appropriate to a qualitative research approach for collecting and analysing data for this research (Collis \& Hussey, 2009; Creswell, 2009; Hallebone \& Priest, 2009; Henning et al., 2004).

\section{Research strategy}

The researchers used a case study to investigate the problem. This was appropriate for the inquiry as it allowed the researchers to explore a contemporary phenomenon in its real-life context (Myers, 2009; Perry, 2001).
The researchers obtained their data about retaining Generation X employees in the public service from secondary sources. They obtained their empirical evidence from semistructured interviews. The researchers believed that these would yield richer data than a survey would because they could cross-examine responses to open-ended questions.

The focus was on Generation $X$ public servants. The researchers integrated the themes they derived from each participant into those of the groups and compared their findings with those they noted in the literature.

\section{Research method}

The researchers used an interview guide containing 15 openended questions. They based the questions on the theory in the literature.

The questionnaire consisted of three sections. The first covered demographics (race, gender, salary, educational qualifications, home language and marital status). The second dealt with factors that affect the retention of Generation X employees, and the third covered turnover (i.e. why Generation X employees leave their employers).

\section{Research setting}

The researchers selected ten Generation Xers employed by state departments based in Pretoria for this research. They collected data between September and October 2007, and verified and analysed them between October 2007 and April 2008.

\section{Entrée and establishing researcher roles}

One researcher, who was employed by a state department at the time of the study, approached 10 Generation $X$ colleagues who were willing to participate in the study. The researcher complied with ethical requirements by getting consent from participants and assuring them that the researchers would keep the information they submitted confidential.

Therefore, the researchers did not name participants but numbered them for the study.

The department also gave the researchers permission to conduct the study.

\section{Sampling}

The purpose of the study was to gain a clearer understanding of factors that influence the retention of Generation $X$ public servants. Therefore, the researchers used purposive sampling.

Although there is no ideal sample size for studies using a qualitative approach, there are guidelines for case studies. Eisenhardt (1989) proposes samples of between four and ten. Morse (in Denzin and Lincoln, 1994) suggests six cases whilst 
Creswell (2002, in Onwuegbuzie \& Leech, 2007) prefers between three and five cases.

Consequently, the eight persons who responded to the researchers' invitation to participate were consistent with these guidelines for qualitative case study research.

The unit of analysis was the individual Generation $X$ participant (Babbie, 2007; Perry, 2001).

The main limitation to this study was that the researchers could not generalise the results to the whole population of Generation X employees because of the research design.

The researchers ensured reliability by using a formalised, structured process. If other researchers use the same approach, they should get similar results.

\section{Data collection}

The researchers organised the interviews telephonically with the eight participating Generation $X$ public servants. The researchers thought that the interviewees would know most about the subject. This insured external validity (Perry, 2001).

The researchers held semi-structured interviews with participants. This allowed them to gain a deeper understanding of the context in which participants gave responses and to recognise that the approaches to retention would be unique.

\section{Data capture}

The researchers conducted hour-long semi-structured interviews in places (the homes or offices of the interviewees) and times convenient to them.

The researchers used the retention definition that Frank et al. (2004) proposed as the reference definition throughout the interviews to ensure shared meaning. The researchers increased credibility by clarifying concepts.

The researchers recorded the interviews in notes the interviewer made. They verified the results with interviewees to ensure that the notes reflected what the interviewees had meant.

Although the interviewer was inexperienced, she ensured productive interviews by identifying questions in advance to make sure that all the interviewees answered all the questions. She did not always ask all the questions because some of the answers emerged whilst she was asking other questions.

Therefore, the note taking was painstaking as the interviewer verified all the responses. In retrospect, however, it might have been better to record the interviews as well as take notes. Consequently, taking notes only, instead of supplementing them with audio or video recordings, is a weakness of this study.

\section{Data analysis}

The researchers analysed the notes using content analysis.

The analysis involved searching for phrases and themes and comparing them with predefined categories that emerged from the literature on the retention of Generation $\mathrm{X}$ employees.

The researchers identified common themes and established the importance of themes by identifying which ones the interviewees mentioned repeatedly. The researchers analysed the data manually, because the number of responses was small, by linking the themes to retention factors in the literature.

Furthermore, the researchers could consider latent content as they analysed the data manually. They reduced the risk of losing meaning by allowing for exhaustive categories that dealt with meanings that were similar and relevant to the study.

Consequently, the researchers tried to ensure rigour by not excluding any relevant data or including anything that was irrelevant.

\section{Strategies to ensure data quality}

The researchers ensured rigour by using semi-structured interviews and pre-testing the interview guide with a Generation X public servant who was not a participant.

\section{Reporting}

The researchers used an interpretivist approach to report the findings of the study. This means that the interviewer was part of the meaning-making process.

They adopted the realist approach as described by Fisher (2010). According to the realist approach, concepts exist independently of how people perceive or experience reality. Furthermore, the concepts are cognitively accessible to those observing them. Nevertheless, accessibility does not mean that knowledge is a perfect interpretation of reality. It is only approximately objective. As such, people can know about the concepts relatively objectively (Fisher, 2010).

\section{Findings}

Eight of the ten participants the researchers approached to participate in this inquiry accepted the invitation. They were all Generation Xers according to the definition of Bova and Kroth (2001) as all were between 27 and 43 years old (i.e. born between 1965 and 1981). Furthermore, various South African state departments employed them. They were thus public servants. Therefore, the researchers can accept their responses as relevant to this generation and employment sector.

For ethical reasons, this article does not give the names of the participants or the departments involved. 
The next section gives the biographical information of the participants. The factors that influence their retention follow.

All of the participants were single parents and their language profiles reflected the composition of the South African population. Venda was the most common language. More males than females participated in the research. The qualifications of the participants indicated that these Generation Xers were educated. Five had honours degrees, two had a first degree and one a national diploma. This implies that these Generation $X$ public servants had knowledge and skills that were relevant to their employers. Their positions show this as well. Seven were professionals and one was a technical person. Therefore, they are assets to their employers.

Five of the interviewees' annual salaries fell below R150 000, one earned between R151 000 and R250 000 and two earned between R251 000 and R350 000. The low salaries do not reflect the value of the interviewees.

The participants' profiles follow:

- Participant 1: Held an honours degree, had worked with the current employer for between four and five years and for four or five previous employers. Participant 1 earned an annual salary of between R151 000 and R250 000. Participant 1 had similar experience to participants 2 and 3.

- Participant 2: Held an honours degree, had worked with the current employer for between five and six years and for four or five previous employers. Participant 2 earned an annual salary of between R251 000 and R350 000. The experience of participant 2 was similar to that of participants 1 and 3 .

- Participant 3: Held an honours degree, had worked with the current employer for between five and six years and for four or five previous employers. Participant 3 earned an annual salary of less than R150 000 per annum. The experience of participant 3 was similar to that of participants 1 and 2 .

- Participant 4: Held an honours degree, had worked with the current employer for between two and three years and for one previous employer. Participant 4 earned less than R150 000 per annum.

- Participant 5: Held a first degree, had worked with the current employer for less than one year and for two or three previous employers. Participant 5 earned less than R150 000 per annum.

- Participant 6: Held an honours degree and had worked with the current employer for between one and two years and for one previous employer. The annual salary of participant 6 was below R150 000 per annum.

- Participant 7: Held a technical qualification, had worked with the current employer for between one and two years, for four or five previous employers and earned less than R150 000 per annum.

- Participant 8: Held a first degree, had worked with the current employer for between seven and eight years, for 10 previous employers and earned between R251 000 and R350 000 per annum.
One can determine the loyalty of the Generation Xers to their employers by the length of their tenures.

The tenures of the interviewees with their current employers ranged from less than a year to between seven and eight years. Two participants had been with their current employers for between one and two years, whilst one participant had worked for between two and three years for his current employer. Three participants had worked for between three and four years, four and five years and five to six years respectively.

The participants' tenure shows that they generally stay for short periods with an employer. This is consistent with the observations of Cordeniz (2002).

Consequently, the interviewees are not loyal to their employers, based on the short periods they stayed with one employer. Six of the participants had worked for more than one employer after they entered the labour market. In most cases (four), these interviewees had worked for between four and five employers before joining their current employers, followed by between two and three employers. In one case, the interviewee had worked for more than 10 employers before joining the current employer. The number of previous employers suggests that these participants are nomadic.

Training, both self-initiated and employer-initiated, reflects their loyalty to their skills. The interviewees' responses to training and development support this notion as they all had attended some self- or employer-initiated training programmes. Four participants had initiated the same number of programmes as their employers did. Two participants had initiated more programmes than their employers did. Two participants were satisfied with the programmes their employers initiated (Table 1 reflects these differences).

The biographical information of the participants showed that there was no pattern in qualifications, experience, training, employment tenure or salary. This brief overview of the biographical information of the interviewees suggests that they share the common characteristics of Generation Xers as noted in the literature. Therefore, one can expect that the typical factors that affect the retention of Generation Xers will also affect the participants.

The factors that affect their retention follow.

The prominent factors that emerged during the discussions about retention factors were career growth and development. The next most prevalent factors that affected the retention of these Generation X employees were flexible working conditions, compensation and benefits.

Most Generation Xers the researchers interviewed indicated that their salaries were adequate for what they were doing if their salary increases keep pace with inflation. However, most respondents were not satisfied that their employers were using their skills optimally and understood their poor remuneration because of this. 
TABLE 1: Training and development initiatives.

\begin{tabular}{lcc}
\hline Participant & \multicolumn{2}{c}{ Number of initiatives } \\
\cline { 2 - 3 } & Self-initiated & Employers-initiated \\
\hline 1 & 1 & 0 \\
2 & 3 & 3 \\
3 & 0 & 1 \\
4 & 3 & 3 \\
5 & 1 & 1 \\
6 & 1 & 3 \\
7 & 0 & 3 \\
8 & 3 & 3 \\
\hline
\end{tabular}

Participant 1, for example, mentioned that she was 'unhappy in [her] current position owing to the job itself as well as supervisor's behaviour'. On further questioning, she responded 'the work was unchallenging' and 'did not utilise [her] skills fully'. Furthermore, she pointed out that the 'employer did not pay for the skills of their staff'. Participants 4, 5, 6, 7 and 8 also clearly expressed concern, in differing degrees, about poor pay. However, they were not nearly as upset as Participant 1 about the salary. Participant 4 merely mentioned that he 'felt bad' in general about his remuneration. Participant 5 mentioned that 'the salary should match the service of a person', but did not offer any further comment. Participant 7 was adamant that 'salary should not get behind in terms of inflation'. Participant 8 believed that 'the basic salary of public servants should increase'.

All of these participants indicated that their employers did not use their expertise to their liking, implying job dissatisfaction.

Some of their comments support this idea:

- ' [I] need more duties that hold challenges and opportunities to learn new things' (participant 4)

- 'doing the same duties for a long period of time, become unexciting, especially if the job is not spiced up with training to make it more interesting' (participant 5)

- participants 6 and 7 required a 'better working environment'

- '[I am] not happy with my job' as it was not "challenging"' (participant 8).

- participant 8 believed that the unhappiness will pass as soon as 'I get a challenging job' or at least 'activities that are challenging'. He further indicated that he would leave the organisation for 'new challenges' and 'work that is related' to his education.

Career development might mean that their employers would use the skills of these public servants better. However, interviewees' comments about career development were generally not positive. Career development is the responsibility of supervisors and these comments might reflect the behaviour and attitudes of supervisors.

Participant 2, for example, indicated that 'there are no growth prospects or career advancement opportunities'. These rely on expertise and support the perception that employers do not use current skills and experience fully. Furthermore, 'bad career management' and 'poor performance management systems' perpetuate the situation. This means that employers are not using skills and experience fully.
Only participants 1, 7 and 8 indicated that they were unhappy in their current jobs, mainly because of poor relationships with their direct supervisors.

Participant 2 mentioned that she was happy with her job but unhappy with her supervisor. She pointed out that the 'supervisor is not supporting [her] in solving work related problems' and 'not accommodating the flexibility needs of employees', compounding the frustrations associated with career development and inadequate use of skills and experience. Nevertheless, she 'had taken 50 days sick leave in the last year', without being specific about the nature and duration of the sick leave.

Participant 1 indicated that the supervisor was 'not responsive to the flexibility needs of the staff' and 'did not assist [her] in solving work related problems when required'. According to Participant 1, she would only be happy if she 'changed jobs'.

Participant 7 responded vaguely, mentioning 'a good working environment is required, which can be attained by at least monthly meetings to assist staff in solving their work related problems'. He further implied that he 'had been looked over' for a well-deserved promotion. Participant 8 mentioned that he 'preferred a more challenging job' that was not available and 'flexibility needs were not entirely met'.

Although Participants 3, 4, 5 and 6 indicated that they were happy in their current jobs, they also indicated a lack of challenging work. The researchers asked the participants whether it was easy to change jobs. Most responded that it was not. The main reason they gave was the current economic cycle that did not favour employees. It appears that the nonsupportive attitudes and behaviours of supervisors reflect a breakdown in interaction, whilst interaction is necessary for commitment and engagement.

The researchers grouped the factors that affect the retention of Generation X public servants according to themes:

- organisational factors, which included career, specifically the work content; utilisation of skills; career advancement; work-life balance; compensation; security needs; educational mismatch; and leadership

- the individual, which included drive.

The discussion gives more detail about the findings of the study.

\section{Discussion}

The purpose of the study was to establish which factors affect the retention of Generation X public servants. Generation Xers are more likely to leave their organisations when they are dissatisfied than any other generation. Employers can develop strategies to retain them if they know which factors affect retention.

Although these Generation Xers were knowledge workers according to their qualifications, experience and tenures 
with their current employers, as well as their number of past employers, their compensation did not reflect their status as valuable assets to their organisations.

For this reason, the salaries they earn do not reflect their contributions to creating and sustaining competitive advantage. The responses of the Generation Xers showed that they were aware of, and concerned about, their poor compensation. Dissatisfaction with salary, as part of compensation, is a factor that affects the retention of Generation X employees. Salary is a factor that puts the retention of Generation Xers, especially public servants, at risk (Perrine, 2009; Rose \& Gordon, 2010; Ahlrichs, 2007; Perrine, 2009; Rose \& Gordon, 2010). Niewenhuizen (2009) notes that civil servants are poorly remunerated.

Salary seems to reflect on the value of employees. The participants in this study felt that the salaries their employers paid showed that their employers did not acknowledge them as assets.

This raises questions about the commitment and engagement of these employees. If employers do not acknowledge their employees, they become imperative ingredients for good performance. According to authors like Alrichs (2007), Bova and Kroth (2001), Pfau and Kay (2002), Rodriquez et al. (2003), Salopek (2008) and Taylor (2002), acknowledgement is one of the factors that affects the retention of Generation Xers and contributes to employee commitment and engagement. Hence, the responses of these participants are consistent with what these authors found.

Career-related issues, specifically work content, utilisation of skills and career advancement, are factors that affect the retention of Generation Xers. Work content, utilisation of skills and career development affect tenure.

The comments of these Generation Xers about tenure, current and previous, indicate the mobility of this generation. Consequently, their comments about tenure support the literature in asserting that Generation $X$ employees are nomadic (Ahlrichs, 2007; Cordeniz, 2002; DeMarco, n.d.; Johnson, 2004; Western \& Yamamura, 2006). This implies that Generation Xers will leave if dissatisfied with their working conditions. However, in view of the current economic climate, it seems that the tough labour market deters them from changing jobs as it could adversely affect their security. The interviewees commented that it is not easy to change jobs at the moment because of the current economic climate. The interviewees were all single parents with obligations and commitments to households. This shows that they were protective of their families and is consistent with the findings of (DeMarco, n.d.) on the unique characteristics of Generation Xers.

The responses of these Generation Xers to training and development programmes show that, if their employers did not initiate programmes that met the needs of the interviewees adequately, they initiated programmes themselves.

There seems to be no correlation between these training and development programmes and the qualifications, experience or salaries of the interviewees. Participants 2 and 4 had honours degrees, whilst participant 8 had a first degree. They had attended six programmes each, three of which were self-initiated. Participant 5 had a first degree and had attended two programmes, one of which was self-initiated. Participant 1 , with an honours degree, had attended one selfinitiated programme, whilst Participant 7, with a technical qualification, had attended three employer-initiated programmes.

In checking the responses of the interviewees to other questions, it transpired that those who were more or less satisfied with their current working conditions (participants 3, 5 and 6) did not invest much time and effort on selfinitiated training and development programmes.

However, where interviewees were not entirely satisfied with either their working conditions (participants 1, 2 and 8 ) or work content (participant 4), they initiated training and development programmes to avoid boredom. Therefore, we can regard training as a way of keeping them energised and committed (Flaherty, 2005).

Consequently, it seems that training and development link to the intrinsic features of people, like drive or motivation, rather than to their qualifications, position, tenure and salary. Furthermore, in attending to their own training and development needs, these Generation Xers remain loyal to their skills. This is consistent with the literature (Alrichs, 2007; DeMarco, n.d.; Dibble, 1999; Flaherty, 2005; Pfau \& Kay, 2002; Rose \& Gordon, 2009; Ruch, 2000; Salopek, 2008; Samuel \& Chipunza, 2009; Schacter, 2009; Taylor, 2002; Vaughn, 2008).

The responses of the interviewees support the literature when it comes to growth and development. The interviewees felt that their employers did not use their skills optimally. The led to them feeling bored. This suggests an educational mismatch between the employees and the posts they hold.

When the researchers asked the interviewees why they did not move to greener pastures, they responded that, given the current economic conditions, it is not so easy to change jobs because the job market is tough. Furthermore, given that they were single parents with commitments, it would be risky to venture into unknown territories for longer than they were prepared to endure. This shows that these Generation Xers were concerned about their security and that of their dependants. This concern about security differs from opinions in the literature (Ruch, 2000). Therefore, these Generation Xers reaffirmed that family is important to them (DeMarco, n.d.). This seems to suggest that these participants will suffer the consequences of an unexciting job rather than make their families suffer.

The researchers discussed the responses about flexible working conditions in greater depth to understand them better. Participants indicated that employers supported work-life balance as far as family responsibility, leave and employee-assistance programmes are concerned. However, they did not mention the importance of flexible times and schedules in enabling Generation Xers to accommodate their 
family responsibilities. Their comments about flexibility support the theory about their flexibility needs (Alrichs, 2007; Bova \& Kroth, 2001; Johnson, 2002; Rodriquez et al., 2003; Withers, 2001).

Although the interviewees mentioned leadership less often, it seemed to be an important issue for retention. The leadership of supervisors seems to influence the retention of Generation Xers. The non-supportive nature of their leaders discouraged the interviewees most. Their supervisors did not accommodate their career development and flexibility needs specifically. It seems that their supervisors have let the employees down

The relationship between employees and supervisors is an important issue in the workplace. Supervisors can respond to the needs of employees, especially their career and work-life balance needs, if they know and understand their employees, treat them fairly and are people the employees can trust. Leadership plays an important part in engagement and acts as a precursor to customer service and retention (Cordeniz, 2002; Dewhurst, 2009; Dyer, 2009; Perrine, 2009). Furthermore, job satisfaction is a precursor to engagement.

Clearly, the participants are generally not satisfied with their jobs. More specifically, they are unhappy about how their employers are using their skills and experience or addressing their career development and flexibility needs.

Leadership plays an important part in managing talent. Good management means attracting, developing and retaining the right staff to ensure performance. Consequently, one should not see retention in isolation, but should view talent management as a whole.

The inadequacy of appropriately qualified and experienced senior managers supports the views of Temkin $(2008,2009)$. They are clearly not able to lead, manage talent or ensure the retention of Generation X employees effectively.

\section{Conclusion}

This study set out to identify the factors that affect the retention of Generation X employees in the public service.

The retention of Generation $X$ employees is important because they are the knowledge repositories of organisations. They help to create and sustain competitive advantage and to achieve organisational goals and good performance.

However, Generation X employees are nomadic and they are more likely than any other generation to leave their organisations when dissatisfied. Subsequently, knowing which factors affect their retention could lead to effective retention strategies.

Retention is an integral part of managing talent, although the areas of recruiting and developing staff were not part of this study.

This article fills a gap in the empirical evidence about the factors that affect the retention of Generation X employees in the South African public service.
The findings of the study confirm what the literature notes about the factors that affect the retention of Generation $X$ employees. We can classify the factors that affect retention into compensation, career (which includes work content, utilisation of skills and career advancement), work-life balance, security, educational mismatch and leadership. All of these fall within the ambit of organisations. Motivation, on the other hand, is the responsibility of employees.

When considering the factors that affect the retention of Generation X employees, the role of the leader is paramount. Leaders can directly influence most of the factors. Adapting to the changing world of work, especially the requirements of employees, seems in desperate need of attention.

The researchers recommend that further research into retaining Generation X employees is undertaken in order to generalise the findings. The role of leadership should also be investigated more thoroughly.

\section{References}

Abbott, N.G., White, A.F., \& Charles, M.A. (2005). Linking values and organizational commitment: A correlational and experimental investigation in two organizations. commitment: Acorrelational and experimental investigation in two organizations. Journal of Occupational and
doi:10.1348/096317905X26174

Ashby, F.C., \& Pell, A.R. (2001). Embracing Excellence: becoming an employer of choice to attract and keep the best talent. Paramus: Prentice Hall Press.

Ahlrichs, N. (2007). Retaining four generations at work. TEC Australia \& New Zealand Retrieved October 30, 2009, from http://www.tec.com/au/node/215

Babbie, E. (2007). Practice of business and social research. Belmont, CA: Wadsworth.

Bersin, J. (2008). The business impact of talent management. Banking Strategies, $84(5), 6$.

Bova, B., \& Kroth, M. (2001). Workplace learning and Generation X. Journal of Workplace Learning, 13(2), 57-65. doi:10.1108/13665620110383645

Boxall, P. (1998). Achieving competitive advantage through human resource strategy: towards a theory of industry dynamics. Human Resource Management Review, 8(3), 265-288. doi:10.1016/S1053-4822(98)90005-5

Brown, A.S. (2009). Think of workers as assets. Mechanical Engineering, January, 131 (1), 20.

Business must resolve dire skills shortage. (2008). Business Day. Retrieved November 18,2008 , from http://bis.hosted.inet.co.za/news

Carpenter, M.A., \& Sanders, G. (2009). Strategic Management: A Dynamic Perspective. Upper Saddle River: Pearson International.

Cheney, V., \& Nienaber, H. (2009). Exploring HR perspectives on succession planning as retention aid for engineering professionals: The case of SADRI in 2007/08. Journal of Contemporary Management, 6, 441-462.

Collis, J., \& Hussey, R. (2009). Business research: a practical guide for undergraduate \& post-graduate students. 3rd edition. London: Palgrave Macmillan.

Cook, S., \& Macauley, S. (2009). Talent management: Key questions for learning and Development. Training Journal, July 2009, 37-41.

Cordeniz, J.A. (2002). Recruitment, retention and management of Generation X: A focus on nursing professionals. Journal of Healthcare Management, 47(4), 237-244.

Creswell, J.W. (2002). Educational research: Planning, conducting and evaluating quantitative and qualitative research. Upper Saddle River: Pearson Education. In Onwuegbuzie, A.J. \& Leech, N.L. 2007. A call for qualitative power analysis. Quality and Quantity, 41, 105-121.

Creswell, J.W. (2009). Research design: qualitative, quantitative and mixed approaches. 3rd edition. Thousand Oaks: Sage.

Cunningham, I. (2007). Talent management: making it real. Development and Learning in Organizations, 21(2), 4. doi:10.1108/14777280710727307

David, F.R. (2009). Strategic Management: Concepts and Cases. Upper Saddle River Pearson International.

Dearth of supply chain skills. (2008). Business Times. Retrieved May 25, 2009, from http://bis.hosted.inet.co.za/news

DeMarco, D. (n.d.). 7 strategies to retain Gen-X women. Retrieved October 30, 2009 from http://hr.blr.com/whitepapers.aspx?id=77349

De Vos, A., \& Meganck, A. (2009). What HR managers do versus what employees value: Exploring both parties' views on retention management from a psychological contract perspective. Personnel Review, 38(1), 45. doi:10.1108/00483480910920705

Dewhurst, S. (2009). Does everyone understand what engagement means? Strategic Communication Management, 13(4), 14.

Dibble, S. (1999). Keeping your valuable employees: retention strategies for your organisation's most important resources. New York: John Wiley. 
Dyer, K. (2009). Taking employee engagement to new heights. Strategic Communications Management, 13(4), 1.

Eisenhardt, K.M. (1989). Building theories from case study research. Academy of Management Review, 14(4), 532-550. doi:10.2307/258557

Fegley, S. (2006). Talent Management Survey Report, Society for Human Resource Management. Retrieved April 13, 2007, from http://www.shrm.org/research

Fisher, C. (2010). Researching and writing a dissertation: An essential guide for business students. 3rd edition. Essex: Pearson Education Ltd.

Flaherty, J. (2005). Trainer as a retention agent. Training and Development, 59(2), 61-64.

Frank, F.D., Finnegan, R.P. \& Taylor, C.R. (2004). The race for talent: retaining and engaging workers in the 21st century. Human Resource Planning, 27(3), 12-25.

Grant, R.M. (1996). Toward a knowledge-based theory of the firm. Strategic Management Journal, 17(Winter Special Issue), 109-122.

Grant, R.M. (2010). Contemporary strategy analysis. 7th edition. London: PalgraveMcMillan.

Harvey, D. (2009). Talent strategy is vital. Personnel Today, June 23, 13.

Hallebone, E., \& Priest, J. (2009). Business and management research: paradigms \& practices. London: Palgrave Macmillan.

Heinen, J.S., \& O'Neill, C. (2004). Managing talent to maximize performance. Employment Relations Today, 31(2), 67. doi:10.1002/ert.20018

Helfat, C.E., \& Peteraf, M.A. (2003). They dynamic resources-based view: capability lifecycles. Strategic Management Journal, 24(10), 997. doi:10.1002/smj.332

Henning, E., Van Rensburg, W., \& Smit, B. (2004). Finding your way in qualitative research. Pretoria: Van Schaik.

Hillmer, S., Hillmer, B., \& McRoberts, G. (2004). The real costs of turnover: Lessons from a call centre. Human Resource Planning, 27(3), 34-41.

Holbeche, L. (2009). Aligning human resources and business strategy, 2nd ed. Oxford: Elsevier.

Ireland, R.D., Hoskisson, R.E., \& Hitt, M.A. (2009). The Management of Strategy: Concepts and Cases. Mason: Cengage Learning.

Jamrog, J. (2004). The perfect storm: The future of retention and engagement. Human Resource Planning, 27(3), 26-33.

Jeffrey, A. (2010, 03 June). Growth-focussed policies: Why SA is doing so badly Moneyweb. Retrieved June 04, 2010, from http://www.moneyweb.co.za/mw/ view/mw/en/page

Johnson, M. (2002). Talent magnet: getting talented people to work for you. London: Pearson Education.

Johnson, M. (2004). New rules of engagement: life-work balance and employee commitment. London: Chartered Institute of Personnel Development.

Joseph, D., Ng, K., Koh, C., \& Ang, S. (2007). Turnover of information technology professionals: A narrative review, meta-analytic structural equation modelling and model development. MIS Quarterly, 1(3), 547-577.

Kerr-Phillips, B., \& Thomas, A. (2009). Macro and micro challenges for talent retention in South Africa. SA Journal of Human Resource Management/SA Tydskrif vir Menslikehulpbronbestuur, 7(1), 1-10.

Kesbey, D. (2008). Talent Management. Training Journal, December 2008, 34.

Kontoghiorghes, C., \& Frangrou, K. (2009). The association between talent retention, antecedent factors and consequent organizational performance. S.A.M. Advanced Management Journal, Winter, 74(1), 29-58.

Kotler, P., \& Armstrong, G. (2000). Principles of Marketing. Upper Saddle River: Prentice-Hall.

Lawless, A. (2005). Numbers and Needs: Addressing Imbalances in the Civil Engineering Profession. Halfway House: South African Institution of Civil Engineering.

Lee, T.W., \& Maurer, S.D. (1997). The retention of knowledge workers with the unfolding model of voluntary turnover. Human Resource Management Review 7(3), 247-275. doi:10.1016/S1053-4822(97)90008-5

Lewis, R.E., \& Heckman, R.J. (2006). Talent management: a critical review. Human Resource Management Review, 16, 139-154. doi:10.1016/j.hrmr.2006.03.001

Linne, L. (2009). Obtaining and retaining the best talent. Rough Notes, 152(6), 32-34.

Lockwood, N.R. (2006). Talent management: driver for organizational success. $H R$ Magazine, 51(6).

Meyer, J.P., Allen, N., \& Smith, A.C. (1993). Commitment to organizations and occupations: extension and test of a three component conceptualization. Journal of Applied Psychology, 78(4), 538-551. doi:10.1037/0021-9010.78.4.538

Meyer, J.P., \& Smith, C.A. (2000). HRM practices and organizational commitment Test of a mediation model. Canadian Journal of Administrative Sciences, 17(4) 319-330. doi:10.1111/j.1936-4490.2000.tb00231.x

Myers, M. (2009). Qualitative research in business and management. Thousand Oaks: Sage.

Morse, J.V. (1994). The dance of qualitative research designs: metaphor, methodology and meaning. In Denzin, N.K., \& Lincoln, Y.S. 1994. Handbook of qualitative research. Thousand Oaks: Sage.
Mosley, V., \& Hurley, M. (1999). IT skill retention. Information Management \& Computer Security, 7(3), 129-132. doi:10.1108/09685229910279425

Munsamy, M., \& Bosch-Venter, A. (2009). Retention factors of management staff in the maintenance phase of their careers in local government. SA Journal of Human Resource Management/SA Tydskrif vir Menslikehulpbronbestuur, 7(1), 1-9.

Naveen, L. (2000). Management turnover and succession planning in firms. Arizona State University. Department of Finance.

Niewenhuizen, C. (2009). Scarcity, requirements and remuneration of applicants with management qualifications in the private-, public- and higher education sectors. Journal of Contemporary Management, 6, 310-234.

Operation getthehellout. (2008). Business Day. Retrieved April 19, 2009, from http:// bis.hosted.inet.co.za/news. Accessed on 30 October 2009

Parastatals need to fill 6000 jobs (2010, 18 May). Cape Times.

Perry, C. (2001). Case research in marketing. The Marketing Review, 1, 303-323. doi:10.1362/1469347002530790

Perrine, J.L. (2009). Recruitment and retention report: Strategies to boost RN retention. Nursing Management, 40(4), 20-22. doi:10.1097/01. NUMA.0000349685.24165.21, PMid:19346920

Peteraf, M.A. (1993). The cornerstones of competitive advantage: a resourcebased view. Strategic Management Journal, 14(3), 179-191. doi:10.1002/ smj.4250140303

Pfau, B.N., \& Kay, I.T. (2002). The human capital edge: 21 people management practices your company must implement (or avoid) to maximize shareholder value. New York: McGraw-Hill.

Pillay, R. (2009). Retention strategies for professional nurses in South Africa. Leadership in Health Services, 22(1), 39. doi:10.1108/17511870910928010

Powell, M.D., \& Meyer, P. (2004). Side bed theory and the three-component mode of organizational commitment. Journal of Vocational Behavior, 65, 157-177. doi:10.1016/S0001-8791(03)00050-2

Rodriquez, R.O., Green, M.T., \& Ree, M.J. (2003). Leading Generation X: Do the old rules apply? Journal of Leadership and Organisational Studies, 9(4), 67-75. doi:10.1177/107179190300900406

Rose, D.M., \& Gordon, R. (2010). Retention practices for engineering and technical professionals in an Australian Public Agency. Australian Journal of Public Administration, 69(3), 314-325. doi:10.1111/j.1467-8500.2010.00693.x

Ruch, W. (2000). How to keep Gen X employees from becoming X-Employees. Training and Development, 54,40-44.

Salopek, J.J. (2008). Retention buzz. Training and Development, January, 62(1), 23-25.

Samuel, M.O., \& Chipunza, C. (2009). Employee retention and turnover: Using motivational variables as a panacea. African journal of Business Management 3(8), 410-415.

Schachter, D. (2009). Staff retention: Preparing for the recovery. Information Outlook 13(3), 36-37.

Sherry, S. (2008). Cultivating talent, Financial Mail, 21 November. Retrieved October 30, 2009, from http://bis.hosted.inet.co.za/news

Shortage of skills across the board. (2008). Business Day, 23 July. Retrieved October 30, 2009, from http://bis.hosted.inet.co.za/news

Skills shortage is SA's Achilles heel. (2008). Financial Mail, 1 August. Retrieved October 30, 2009, from http://bis.hosted.inet.co.za/news

Smith, G.P. (2009, 27 October). Recruitment and retention strategies: how to attract keep and motivate today's workforce. Manager Wise. Retrieved October 27 2009, from http://bis.hosted.inet.co.za/news accessed

Taylor, C.R. (2002). The talent focus. Training and Development, 56(12), 26-31.

Temkin, S. (2008). Quarter of senior manager jobs held by blacks, Business Day, 2 December. Retrieved October 30, 2009, from http://bis. hosted.inet.co.za/news

Temkin, S. (2009, 16 July). Firms put survival ahead of quotas, Business Day.

Truss, C., \& Gratton, L. (1994). Strategic human resource management: a conceptual approach. International Journal of Human Resource Management, 5(3), 663-686.

Vaughn, B. (2008). The top 10 incentives to recruit and retain Generation X employees. Retrieved October 30, 2009, from http://diversitynetwork.dtui.com/members/ dtui/blog/VIEW/

Vittori, S. (2007). The employment contract and the changed world of work. Place unknown: Ashgate Pub Co.

Western, J.W., \& Yamamura, J.H. (2006). Generational Preferences for work environment fit: effects on employee outcomes. Career Development International, 12(2), 150-161. doi:10.1108/13620430710733631

Williams, N. (2008). Employers pay price for staff retention failings. Personnel Today, 15 July, 47.

Withers, P. (2001). Retention strategies that respond to worker value, Workforce Retrieved February 27, 2007, from http://www.workforce.com 